\title{
UMBARA
}

Indonesian Journal of Anthropology

Volume 5 (2) Desember 2020 || eISSN 2528-1569

pISSN 2528-2115 || http://jurnal.unpad.ac.id/umbara

DOI : 10.24198/umbara.v5i2.30663

\section{Etnografi Garna Tentang Kebudayaan Baduy \\ (Catatan untuk Mengenang Prof H. Judistira K. Garna, Ph.D)}

\author{
Ade Makmur Kartawinata \\ Jurusan Antropologi, FISIP, Universitas Padjadjaran \\ amkartawinata@gmail.com
}

\begin{abstract}
This article explains the way Judistira K Garna describing Baduy culture. His ethnographic work is about the life of the Baduy people and their response to changes from the perspective of the Baduy themselves. Koentjaraningrat referred Judistira's work as "Ethnography of Garna" which resulted from a functional interpretation of Baduy culture. Garna's work explains things that are not in terms of tools to control their life order, but are sources for understanding them. The values of their life we often do, we also seek, as far as possible, should be accommodated in the flow of their life. If the expected results of socio-cultural change are achieved in Baduy, both in the form of social institutions and new procedures, it will not only be the work of outsiders but also the result of their willingness and efforts to accept.
\end{abstract}

Keywords: Thick description, Baduy, Ethnographic Garna, functional interpretation, socio-cultural change

\begin{abstract}
Abstrak
Artikel ini membahas cara Judistira Garna menggambarkan kebudayaan Baduy dengan menampilkan kehidupan orang Baduy dan respons mereka terhadap perubahan dari perspektif orang Baduy itu sendiri. Koentjaraningrat menyebut karya J Garna sebagai "Etnografi Garna"; sebuah etnografi yang dihasilkan dari tafsir fungsional budaya Baduy. Etnografi Garna tidak bertujuan untuk menguasai tatanan hidup Baduy, tetapi justru menjadi sumber untuk memahami kehidupan Baduy secara menyeluruh Nilai-nilai hidup Baduy terakomodasikan dalam alur kehidupan yang mereka langsungkan setiap saat. Bila terdapat perubahan sosial budaya yang diharapkan, baik berupa institusi sosial maupun tata cara baru di Baduy, hal itu bukanlah hasil kerja orang luar belaka tetapi hasil kesediaan dan upaya Baduy menerima perubahan itu.
\end{abstract}

Kata Kunci: Thick description, Baduy, Etnografi Garna, tafsir fungsional, perubahan sosial budaya

\section{Pendahuluan}

Langkah awal dalam penulisan artikel mengenal pemikiran Judistira mengenai antropologi ini, didahului dengan mengumpulkan tulisan-tulisan beliau tentang ke- budayaan yang pernah penulis simpan, salah satunya adalah karya etnografi kebudayaan Baduy. Judistira terus mengkaji kebudayaan Baduy sampai akhir hayatnya. Beliau telah 
memberikan gambaran etnografis yang utuh mengenai urang Kanekes sebagai kesatuan sosial yang berbeda dari kesatuan sosial lainnya di Kecamatan Leuwidamar Kabupaten Lebak Provinsi Banten. Bahkan, beliau juga telah menunjukkan gambaran bahwa urang Kanekes berbeda dengan kesatuan sosial lainnya di Pulau Jawa.

Judistira Garna mengatakan bahwa urang Kanekes atau akrab dikenal dengan sebutan orang Baduy merupakan kesatuan sosial yang telah mengamalkan kebudayaannya tanpa meninggalkan warna budaya setempat. Hal ini juga dinyatakan Lee Khoon Choy (1976, 1999), sejak ratusan tahun yang lalu yang menganggap bahwa suku ini memiliki tradisi dalam kehidupan masyarakat yang mempunyai kemampuan untuk menyerap penetrasi budaya Barat tanpa meninggalkan kebudayaan yang diturunkan dari leluhurnya. Kajian-kajian Judistira K. Garna menggambarkan mengenai upaya orang Baduy mempertahankan budayanya di tengah arus perubahan yang begitu deras menerpa kehidupan mereka tanpa meninggalkan akar budayanya.

Orang Baduy yang hidup di Desa Kanekes dapat bertahan, meski luas lahan garapan yang terbatas. Mereka mempraktikkan pertanian berpindah dan penanaman padi kering melalui teknik slash and burn atau disebut perladangan atau ngahuma (Iskandar, 1992; Iskandar dan Budiawati, 2017). Cara penggarapan pertanian perladangan atau ngahuma sangat memerlukan lahan yang luas. Demikian juga luas wilayah desanya yang dibentuk pada masa pemerintahan kolonial masih tetap seperti awal terbentuknya. Luas lahan garapan yang terbatas dan luas wilayah desa yang tidak bertambah, tetapi mereka dapat bertahan hidup dengan jumlah penduduknya semakin bertambah. Hal ini karena mereka memiliki syarat-syarat pertanian guna mempertahankan kehidupannya.

Etnografi tentang kebudayaan Baduy yang disusun Judistira Garna ingin menjawab upaya orang Baduy dapat mempertahankan kebudayaannya. Banyak tulisan Garna yang menyiratkan pertanyaan tentang orang Baduy menjaga keberlanjutan kebudayaannya, yaitu "bagaimana syarat-syarat guna mempertahankan budaya Baduy tetap berlanjut, bagaimana orang Baduy menjawab tantangan atas perubahan yang gencar menerjang budaya mereka, apakah mereka memiliki mekanisme budaya yang dijadikan pedoman untuk menghadapi kehidupan", dan pertanyaan-pertanyaan lain yang terkait dengan kajian etnografis. Jawaban atas pertanyaan-pertanyaan itu terurai dari banyak karya etnografi mengenai kebudayaan Baduy yang digambarkan Judistira.

Berkenaan dengan kajian yang dilakukan Judistira Garna itu, Koentjaraningrat (1988:46), dalam tulisannya yang bertajuk Tafsir Kebudayaan, dengan contoh kebudayaan Baduy, menyebutkan bahwa karya Judistira sebagai "Etnografi Garna tentang Kebudayaan Baduy". Oleh karena itu, tulisan ini ingin memaparkan cara Judistira Garna mengungkapkan kehidupan sehari-hari urang Kanekes dalam menyikapi perubahan melalui apa yang disebut Koentjaraningrat sebagai "Etnografi Garna".

\section{Kajian Pustaka}

Uraian mengenai orang Baduy dan kebudayaannya belakang ini begitu tersebar luas, tulisan-tulisan lepas dan buku-buku yang menyeritakan tentang kehidupan sosial dan budaya Baduy. Tulisan itu dimulai dari kisah perjalanan menembus kawasan Desa Kanekes sampai membahas perubahan kehidupan yang sedang menerpa warga Desa Kanekes. Tulisan dan buku-buku itu pun bercerita tentang kekaguman dan keunikan dari yang mereka lihat, dibandingkan niat untuk benar-benar memahami keadaan sosial, 
budaya dan lingkungan hidup orang Baduy (Kartawinata, 2012). Kadangkala, uraian yang disuguhkan itu mengutamakan pandangan bahwa orang Baduy itu memiliki kehidupan yang berbeda dengan kehidupan para penulisnya. Hal itu menjadikan orang Baduy dianggap aneh sehingga mereka menyatakan terkagum-kagum atas apa yang mereka alami selama menjelajah kawasan Desa Kanekes.

Konon mereka merasa kagum karena budaya Baduy masih bisa dengan keaslian kebudayaannya. Namun, mereka lupa bahwa kehidupan sosial budaya masa kini yang ditentukan oleh pasar yang selalu memperhitungkan nilai ekonomi berupa uang begitu besar menerpa kehidupan orang Baduy. Kisah perjalanan mereka yang diwujudkan ke dalam tulisan-tulisan lepas dan buku mengenai ungkapan emosi penulisnya atas apa yang mereka lihat dan rasakan selama berada di Desa Kanekes. Semua tulisan lepas dan buku-buku itu, amat bermanfaat sebagai kumpulan informasi tentang budaya Baduy.

Kartawinata (2012), menyatakan bahwa dari beragam tulisan lepas dan buku yang mengisahkan budaya Baduy, hanya sedikit tulisan lepas dan buku yang disusun berdasarkan suatu kajian mendalam yang mengungkapkan hal-ihwal alam budaya dan alam sosial di kawasan Desa Kanekes sejak jaman Indonesia sebelum merdeka sampai hari ini. Buku yang ditulis N.J.C Geise yang berjudul Badujs en Moslems in Lebak Parahiang, Zuid-Banten (1952), sebagai karya etnografi dari segi metodologi dan teoretik. Karya ini yang dijadikan pijakan dalam menyelidiki kehidupan orang Baduy dan hubungannya dengan muslim yang ada di sekitar Desa Kanekes. Demikian juga, buku Orang Baduy karya Judistira K. Garna yang berjudul Tangtu Telu Jaro Tujuh Kajian Struktural Masyarakat Baduy di Banten Selatan Jawa Barat Indonesia, merupakan karya etnografi Baduy yang mengungkapkan seluk beluk kehidupan orang Baduy untuk menjaga keberlanjutan kebudayaannya dari sisi pandangan orang Baduy itu sendiri.

Selain itu, Koentjaraningrat (1988:38-46) memberikan ulasan pada tulisannya berjudul Tafsir Kebudayaan Dengan Contoh Kebudayaan Baduy, dalam buku Baduy dari Inti Jagat yang disunting oleh Nurhadi Rangkuti (1988). Dalam tulisannya, Koentjaraningrat mengatakan bahwa tafsir struktural Geise mengenai kebudayaan Baduy dan Etnografi Garna tentang kebudayaan Baduy lebih condong ke arah tafsir historikal dan tafsir fungsional. Dalam pengertian itu, Koentjaraningrat menyatakan bahwa kedua karya etnografi tersebut masing-masing memberikan arti penting bagi perkembangan ilmu antropologi di Indonesia.

Di dalam konteks Etnografi Geise dan Etnografi Garna tersebut, karya tersebut turut dipengaruhi dengan kehadiran karya Etnografi Jul Jacobs tahun 1891, di bawah judul De Badoej's dalam Bahasa Belanda yang kemudian dialihbahasakan ke Bahasa Indonesia oleh Judistira K. Garna dan Salam Hardjadilaga (2012) dengan judul Etnografi Jul Jacobs Orang Baduy dari Banten. Dalam buku karya Jul Jacobs, terdapat deretan panjang dalam daftar pustaka disertasi Geise, demikian juga dalam daftar pustaka buku Orang Baduy dan disertasi Judistira K. Garna (Kartawinata, 2012). Itu artinya kedua karya itu terinspirasi dari kehadiran buku karangan Jul Jacobs, meski tahun kajiannya begitu beda jauh waktunya. Jul Jacobs menceritakan Orang Baduy di tahun 1890-an, sedangkan Geise tahun 1950-an, dan Judistira K. Garna, tahun 1980-an. Dari ketiga tulisan itu dapat diperiksa perjalanan panjang kebudayaan Baduy dalam menghadapi perubahan yang terus-menerus menerpa kehidupan orang Baduy.

Menilik ketiga etnografi yang disusun pada masa-masa yang berbeda itu, tentunya hal ini menimbulkan pertanyaan, "apakah orang Baduy ini akan punah atau akhir mereka telah dekat?" dan dijawab dengan kata, "tidak!". 
Namun, pernyataan ketiga penulis etnografi kurang sejalan karena angka kematian bayi terhitung tinggi dan di mana rata-rata dalam satu keluarga terdapat hampir tidak lebih dari dua anak. Walaupun demikian, mereka yang tetap hidup dan berkembang dan melanjutkan perjuangan kelangsungan keberadaan suku bangsa itu dengan tersedianya syarat-syarat guna mempertahankan kehidupannya.

Disertasi Geise maupun Disertasi Garna jelas menyebutkan syarat-syarat guna mempertahankan kehidupan budaya Baduy. Bagaimana orang Baduy menjawab tantangan atas perubahan yang setiap saat menerjang kehidupan budayanya itu. Mereka memiliki mekanisme budaya yang dijadikan pedoman dalam menghadapi kehidupan. Kata "teu wasa", dan "buyut" yang selalu diucapkan merupakan cerminan dalam mentaati serta menjalankan pikukuh sebagai ajaran yang diamalkan dalam kehidupan kesehariannya. Cerita tentang ajaran itu tampaknya terus dipegang teguh oleh orang Baduy berdasarkan kajian yang diungkapkan Jacobs, Geise, dan Garna. Kajian tersebut saling berbeda waktu dan situasi yang berlainan, namun kajian itu mengarah pada satu penjelasan yang sama, yaitu keberlangsungan kebudayaan orang Baduy. Kebudayaan orang Baduy selalu identik dengan mempertahankan keberadaan leluhurnya, termasuk menerima ajaran yang diturunkan dengan penuh ketaatan dan penghormatan.

Pencerahan atas ajaran-ajaran itu selalu dibagikan setiap melakukan kegiatan ritual dan ritus yang bersifat kolektif maupun individual (Geise, 1952; Garna, 1988a). Walaupun ritus yang lebih bersifat individual, seringkali hal ini diwujudkan dalam aktivitas perilaku kesehariannya yang serba sederhana dan bersahaja. Demikian pula, ritual yang bersifat kolektif selalu mewarnai setiap mengawali dan mengakhiri aktivitas pertanian yang diadakan dengan penuh khidmat untuk mengikat kebersamaan mereka. Hal mengikat kebersamaan orang Baduy bukan saja dengan sesamanya, tetapi juga dengan para leluhurnya atau karuhun, seperti ngalaksa, kawalu, dan seba. Ritus dan ritual bagi orang Baduy dijalankan dengan penuh keyakinan akan ajaran dari leluhurnya agar selalu melakukan pengabdian serta penyerahan diri kepada Batara Tunggal.

Keyakinan di atas juga serupa dengan pendapat Lee Khoon Choy (1999:168), dalam bukunya bertajuk: A fragile nation: the Indonesian crisis, Bab 4, tentang The Baduis The Isolationists, mengambarkan sebagai ... 'They are one of the most puritanical peoples still living in this world and try truly to make peace with nature. They believe that their God is the only true God. Mereka adalah salah satu bangsa paling puritan yang masih hidup di dunia ini dan benar-benar berusaha berdamai dengan alam. Mereka percaya bahwa Tuhan mereka adalah satu-satunya Tuhan yang benar. Mengenai hal itu, Lee mengungkapkan bahwa melalui keyakinan orang Baduy tersebut ia tertarik untuk mengkaji kehidupan orang Baduy. Hal itu sebagaimana yang dikatakannya “... Itulah pertama kalinya saya mengetahui tentang orang Baduy dan memulai untuk mengambil minat dalam kelompok minoritas ini yang telah hidup dalam isolasi sejak kedatangan Islam ke Indonesia pada sekitar tahun 1523. Ketika agama Islam menyapu Jawa Barat, sekelompok orang diyakini sebagai keturunan Kerajaan Pajajaran lama menolak untuk masuk Islam". Orang-orang itu yang berdasar pada keyakinan Lee sekarang ini biasa disebut sebagai orang-orang Baduy. Mereka yang melarikan diri ke gunung dengan membawa serta agama dan cara hidup mereka yang terpelihara dengan baik sampai sekarang ini. Untuk menjalankan kehidupannya itu, Lee (1999) mengatakan orang-orang Baduy tampaknya tidak terlalu peduli dengan masalah-masalah dunia luar. Menurut Benyamin (2016), hal terpenting bagi mereka adalah dibiarkan hidup sendiri, cara hidup sendiri, dan tetap memelihara batas suci mereka tidak dilanggar siapapun.

Dari uraiannya itu, Lee (1999) berpendapat 
tentang asal usul orang Baduy di mana bisa jadi menurut keyakinan dan alasan yang dibuatnya benar. Pendapat itu dikuatkan Saleh Danasasmita (1985), yang menyebutkan bahwa orang Baduy adalah keturunan dari Keraton Pajajaran yang melarikan diri ke sebelah selatan Banten dan terdesak oleh serangan Sultan Hasanudin yang menyebarkan agama Islam di kawasan itu. Bagi penulis lain, mereka pendapat tentang asal usul orang Baduy itu kurang tepat, seperti anggapan Geise bahwa mereka adalah orang-orang setempat atau orang Banten Selatan. Orang setempat lah yang lebih memberikan gambaran jelas terutama jika dikaitkan dengan unsur-unsur budaya Banten selatan. Hal ini seperti saat ini kita masih bisa ditemui di wilayah Sukabumi sebelah selatan di mana terdapat masyarakat yang menerapkan pola perkampungan, bentuk rumah, kepercayaan dan adat istiadat, serta sistem kepemimpinan yang mirip dengan orang Baduy (Garna, 1973).

Perdebatan tentang asal usul dan sebutan orang Baduy terus berlaku. Orang Baduy sendiri mengaku bukan berasal dari Keraton Pajajaran atau pun dari Banten, melainkan mereka adalah orang-orang setempat yang sudah berada di sana lama sebelum pengaruh Islam tiba dan mencoba mengubah kepercayaan setempat. Sebutan Baduy itu sendiri sebagaimana dikemukakan Pleyte (1909), kata Baduy itu tidak ada konotasi sebagai kata hinaan dan juga tidak ada kaitannya dengan kata Badwi, tetapi nama Baduy berasal dari kata Cibaduy, nama sungai di sebelah utara Desa Kanekes. Mereka juga menyebut nama kampung atau tempat bermukim yang telah memberi arti penting dalam kehidupan mereka. Oleh karena itu, tidak mengherankan apabila sebutan urang Kanekes dipakai oleh mereka sesuai dengan nama tempat atau sebutan desa tempat tinggalnya, sebutan yang menekankan hakekat dan nilai budaya mereka (Garna, 1988b). Kini mereka pun menurut Garna (1988b), menyebut diri sebagai orang Baduy atau urang Kanekes. Sebutan itu bukan hanya disandangkan oleh orang luar, tetapi sebutan itu sudah melekat bagi mereka yang tinggal di Desa Kanekes dan urang Kanekes yang bertempat tinggal di kampung-kampung dangka yang berada di luar Desa Kanekes.

Namun, cerita dari Jacobs, Geise, dan Garna dari abad ke-20 itu nyatanya masih dapat dijumpai pada abad ke-21 ini. Dengan menelaah buku etnografi dari ketiga etnografer tersebut, penulis dapat menggambarkan suasana kehidupan orang Baduy saat itu. Suasana kehidupan mereka masih bisa dijumpai di kampung-kampung tangtu, yaitu Cibeo, Cikartawana, dan tangtu Cikeusik, bahkan masih juga terasa suasana yang digambarkan para etnografer tersebut di kampung-kampung panamping seperti Kaduketer, Cicatang, dan panamping Cisagu.

Jika demikian, apakah kebudayaan Baduy masih bertahan seperti apa yang ditulis Jacobs, dan Geise dalam buku etnografinya itu, atau sudah berubah sejalan dengan perjalanan panjang waktu yang ditempuh warga Desa Kanekes dalam mengarungi kehidupan di abad ke-21? Untuk itulah, tulisan ini mengungkapkan hal ihwal yang terkait dengan kebudayaan Baduy melalui etnografi Garna tentang bagaimana orang Baduy menyikapi perubahan.

\section{Metode Penulisan}

Tulisan ini disusun dengan menggunakan metode penulisan deskriptif analisis melalui studi kepustakaan dan dokumen. Di dalam penulisan ini, penulis menggunakan sumber utama berupa kepustakaan dan dokumen untuk memberikan gambaran dan menjelaskan objek penulisan. Penulis kemudian menganalisis kembali sebagaimana dikemukakan oleh Smith (2009), Hodder (2009), dan Kartodirdjo (1993) hingga diperoleh gambaran tentang bagaimana Judistira Garna menyusun dan mengungkapkan sebuah etnografi kebudayaan Baduy. Hasil dari etnografi kebudayaan Baduy itu kemudian dinyatakan Koentjaraningrat sebagai "Etnografi Garna". 
Kepustakaan dan dokumen ini dilihat berdasarkan pada sumber-sumber utama yang dalam kajian kepustakaan dan dokumen dikatakan sebagai sumber primer (Smith, 2009; Hodder, 2009; dan Kartodirdjo, 1993). Hal ini karena merupakan karya asli yang ditulis oleh Judistira Garna yang melihat, mengalami, atau mengerjakan sendiri kegiatan yang berupa penelitian, laporan hasil penelitian, disertasi, dan artikel atau makalah. Selain itu, juga sumber sekunder berupa tulisan dan dokumen tentang orang Baduy di luar penelitian yang dilakukan Judistira dan yang tentunya tidak langsung disaksikan atau dialami sendiri oleh penulis. Sumber sekunder dalam penulisan ini adalah buku-buku yang ditulis seperti oleh: (1) Jacobs, J. (2012) dengan judul Etnografi Jul Jacobs Orang Baduy dari Banten. Alih Bahasa Salam Hardjadilaga dan Judistira K. Garna; (2) Geise, N. (1952) dengan judul Badujs en Moslims in Lebak Parahiang Zuid Banten; dan (3) Koentjaraningrat (1988) dengan judul Tafsir Kebudayaan, dengan contoh Kebudayaan Baduy, dalam N. Rangkuti, Orang Baduy Dari Inti Jagat, serta buku dan artikel lain.

Serangkaian kegiatan dalam penulisan ini dengan diawali pengumpulan pustaka dan dokumen, membaca, mencatat, dan mengolah bahan tersebut untuk kemudian dideskripsi dan dianalisis sehingga wujud sebuah catatan mengenang Judistira yang terkait dengan "Etnografi Garna". Zed (2014) mengatakan dalam penulisan kepustakaan dan dokumen serupa ini terdapat empat ciri utama yang penulis perhatikan, yaitu: (1) penulis berhadapan langsung dengan teks; (2) informasi atau data diperoleh langsung dari pustaka dan dokumen itu artinya penulis tidak terjun langsung ke lapangan; (3) data pustaka dan dokumen adalah sumber primer dan sekunder, dalam arti bahwa sumber primer adalah penulis memperoleh dan menyimpan pustaka dan dokumen dari Judistira ketika beliau masih ada, itu artinya kepustakaan dan dokumen bisa disebut orisinal sebagai tulisan beliau, sedangkan sumber sekunder bahan atau data kepustakaan bukan yang ditulis Judistira yang fungsinya untuk memberikan ulasan atau menguatkan analisis; dan (4) pustaka dan dokumen yang dijadikan objek penulisan ini tentunya tidak dibatasi oleh ruang dan waktu.

Berdasarkan keempat ciri-ciri tersebut, disusunlah sistematika penulisan sebagai berikut: pendahuluan, kajian pustaka, metode, "Etnografi Garna": tafsir mengenai kebudayaan Baduy, pendekatan dan proses, pergeseran wilayah, agama, kelompok asal keturunan, kampung dan ikatan kerabat, dan simpulan serta dilengkapi dengan daftar pustaka. Dengan sistematika penulisan seperti itu, maka dapat diperoleh gambaran tentang bagaimana Etnografi Garna yang sebenarnya.

\section{Hasil dan Pembahasan}

\section{Etnografi Garna}

\section{Tafsir Kebudayaan Baduy}

Tafsir mengenai kebudayaan Baduy ini dilakukan Koentjaraningrat (1988) dengan mengambil contoh dari buku Orang Baduy karya Judistira Garna (1987). Sebelum menafsirkan kebudayaan Baduy dari sudut pandang tafsir kebudayaan, Koentjaraningrat menyebutkan "Etnografi Garna" sebagai karya terpenting mengenai kebudayaan Baduy.

Menurut Koentjaraningrat, Etnografi Garna dihasilkan dari tafsir historikal yang mengacu ke sejarah dari kebudayaan yang sedang diteliti atau dijelaskannya. Apabila kebudayaan Baduy menggunakan pengetahuan dalam kehidupan masyarakatnya, maka mereka juga berusaha keras untuk tidak menggunakan unsur-unsur kebudayaan luar. Salah satunya dengan tidak mengenal dan memakai wadah dan periuk belanga yang terbuat dari tembikar, tetapi menggunakan bambu untuk menampung serta menyimpan benda cair. Keadaan ini yang ditafsirkan peneliti dengan keterangan bahwa orang Baduy yang dalam tahun 1983 berjumlah lebih dari 
4500 orang itu (Garna, 1985:29) $)^{1}$, merupakan sisa-sisa penduduk asli di Jawa Barat dari zaman sebelum ada pengaruh kebudayaan Hindu di daerah Jawa Barat².

Selain menerangkan mengapa orang Baduy tidak mengenal teknik pembuatan tembikar, Koentjaraningrat dalam buku Orang Baduy mengatakan keadaan itu juga mengukuhkan hipotesa bahwa mereka adalah penduduk Jawa Barat $^{3}$ dan meniadakan hipotesa mengenai mereka adalah pelarian orang Jawa Barat dari kerajaan Hindu yang diusir para penganut agama Islam. Selain itu, Koentjaraningrat, etnografi Garna ini menggambarkan kebudayaan Baduy mengunakan tafsir fungsional. Tafsiran ini bertujuan menerangkan guna atau manfaat dari suatu unsur atau gejala kebudayaan, baik untuk memenuhi kebutuhan berlangsungnya suatu gagasan perilaku ataupun suatu benda kebudayaan fisik dalam kehidupan masyarakat Baduy.

Koentjaraningrat menunjukkan contoh-contoh terkait etnografi Garna, seperti fungsi dari pembagian pemukiman orang Baduy ke dalam bagian Baduy dalam [tangtu] dan Baduy Luar [panamping] dimaksudkan untuk menjaga gagasan mereka mengenai bagian inti yang bersifat keramat dan bagian luar yang sekuler. Fungsi dari tutulak di tengah-tengah huma (ladang) untuk menolak ruh jahat atau siluman yang berada di sana mengganggu para peladang. Di samping itu, tutulak juga berfungsi untuk menolak orang yang tidak berkepentingan mempergunakan atau merebut ladang garapannya. Fungsi dari umpak atau batu yang menyangga tiangtiang rumah untuk mencegah serangga (rayap) merusak tiang-tiang tersebut.
Tafsir simbolik tentu saja juga dapat menerangkan berbagai unsur dan gejala kebudayaan yang menyangkut tradisi, bila memiliki pemahaman yang sama terutama dengan pendirian ahli antropologi Belanda J. Van Baal dalam Koentjaraningrat mengatakan bahwa sejumlah tingkah laku religi mengandung unsur-unsur yang bertujuan melakukan komunikasi simbolik dengan para penghuni alam supernatural atau alam gaib. Hal itu seperti ditemui pada etnografi Garna, yaitu adanya adat istiadat Baduy yang melarang masyarakatnya bersawah di tanah keramat. Tafsir orang Baduy sendiri mengatakan bahwa untuk membuat sawah, orang harus mencangkul serta membajak tanahnya. Perbuatan itu tentu mengganggu roh-roh para leluhur mereka yang banyak berada di sekitar tanah keramat.

Sifat tafsir tersebut menurut Koentjaraningrat adalah simbolik. Hal ini karena mencangkul dan membajak dikaitkan dengan tingkah laku mengaduk-ngaduk tanah, dan tingkah laku mengaduk-ngaduk diasosiasikan dengan mengganggu ketenangan leluhur dan ruh-ruh yang telah hidup tenang. Di samping tafsir orang Baduy yang dapat disebut tafsir asli itu, juga terdapat tafsiran peneliti yang disebut tafsir ilmiah. Menurut Koentjaraningrat, peneliti menafsirkan bahwa pelarangan membuat sawah di tanah Baduy keramat merupakan upaya untuk menolak teknologi luar dan mempertahankan keaslian serta sifat eksklusif kebudayaan Baduy umumnya. Sifat tafsir ilmiah seperti yang dikembangkan Judistira dalam etnografi Garna itu adalah tafsir fungsional.

Dengan demikian, Koentjaraningrat menyatakan apabila data etnografi Geise diinterpretasikan dengan tafsir struktural. Etnografi Garna yang dijumpai pada buku Orang Baduy

\footnotetext{
${ }^{1}$ Jumlah penduduk Desa Kanekes pada tahun 2017, adalah 11.699 Jiwa, jika disimak dari duabelas desa di KecamatanLeuwidamar, rupanya penduduk Desa Kanekes yang terbanyak atau sekitar 20,81\% dari jumlah keseluruhan penduduk Kecamatan Leuwidamar (Sumber: Kecamatan Leuwidamar dalam Angka Tahun 2018. BPS Kabupaten Lebak).

${ }^{2}$ Ketika tulisan tersebut dibuat Wilayah Orang Baduy masih termasuk ke dalam wilayah Provinsi Jawa Barat.

${ }^{3}$ Kini termasuk Provinsi Banten setelah tahun 2000 berpisah dengan Provinsi Jawa Barat, sesuai Undang-Undang Republik Indonesia Nomor 23 Tahun 2000 tentang Pembentukan Propinsi Banten.
} 
(1987) adalah tafsir yang ditunjukkan oleh peneliti yang banyak mengenal kehidupan sehari-hari orang Baduy dari dalam sehingga cenderung tafsir kebudayaannya lebih bersifat historikal, simbolik, dan fungsional. Berbeda dengan Geise seorang penganut mazhab Leiden, bahan yang digunakannya menurut Koentjaraningrat, adalah data etnografi kebudayaan Baduy yang dipelajarinya dalam tahun 1942 hanya dari luar di mana dengan cara tinggal di Kampung Cipeureu yang berada di luar batas tanah Baduy. Dari sana, ia mewawancarai sejumlah besar orang Baduy yang melewati tempat tinggalnya keluar masuk daerah Baduy.

Data etnografi yang dikumpulkan Geise itu, seperti sistem kekerabatan, hukum adat, dan mitologi Baduy yang kemudian ditafsirkannya secara struktural sesuai dengan konsep Rassers dan De Josselin de Jong. Karena itu. Dari kedua karya etnografi mengenai kebudayaan Baduy tersebut, Koentjaraningrat lalu memberikannya sebutan "Etnografi Geise" dan "Etnografi Garna". Etnografi Geise lebih cenderung ke tafsir struktural sedangkan etnografi Garna, lebih cenderung pada tafsir historikal, simbolik, dan tafsir fungsional.

\section{Pendekatan dan Proses}

Pendekatan dan proses yang dilakukan Judistira K. Garna (1988c) ketika berada di tengah-tengah kehidupan orang Baduy dengan melihat, merasakan, dan menyimak pengembaraan hidup orang Baduy dan liku-likunya dalam mengarungi kehidupan, “... kiranya saya pun harus berterima kasih oleh adanya peluang yang diperoleh dari masyarakat Baduy karena kehadiran saya bersama mereka sejak tahun 1960an tak pernah ditolak". Sambungnya pula, “... Belum lagi berbagai jenis ikatan pertemanan dengan para pelaku budaya tersebut, bahkan dalam kesibukan mereka pun untuk silih berganti menduduki posisi penting dalam tatanan masyarakatnya" (Garna, 1988c).
Berdasarkan pengenalan yang intensif dengan masyarakat Kanekes, Garna dalam penelitiannya itu menerapkan pendekatan empiris yang efektif untuk dapat menyelami alam pikiran masyarakat yang ditelitinya.

Pendekatan empiris ini tentunya merupakan bagian dari pendekatan penelitian yang dilakukan Judistira untuk mendeskripsikan secara mendalam (thick description) dari kebudayaan Baduy. Penelitian ini memerlukan waktu cukup lama di mana peneliti berada di tengah masyarakat yang ditelitinya. Karena itu, gambaran secara mendalam tentang kebudayaan Baduy berhasil dicurahkan Judistira K. Garna melalui disertasi dan lampiran foto beragam mengenai kebudayaan materi dan aktivitas keseharian urang Kanekes baik di sekitaran rumah di perkampungan maupun di ladang atau huma dan di Kebun (kebon), denah kampung-kampung panamping, dan gambar-gambar serta rupa bentuk rumah (imah), leuit, saung lisung, dan saung huma.

Dari disertasinya dapat diperoleh bahwa pengetahuan kebudayaan Baduy secara menyeluruh melalui uraian dan penjelasan mengenai gambaran kehidupan sehari-hari urang Kanekes. Itu artinya deskripsi secara mendalam sebagai penelitian etnografi berhasil ditunjukan peneliti, mulai dari mampu masuk ke dalam suatu objek; secara intuitif mampu melihat perspektif yang muncul, dan pada akhirnya sampai pada empati dan pikiran (makna dan nilai) dari kebudayaan yang ditelitinya (Geertz, 1973; Saat, 2019).

Pengumpulan data kualitatif interpretatif yang dilakukan Judistira itu dengan melihat pada apa yang dikatakan Dilthey (1976), yaitu pengumpulan data kuantitatif interpretatif sebagai pengumpulan data yang tidak memerlukan hukum sebab-akibat, melainkan hubungan di antara singular dan partikular yang bersifat melingkar. Cara ini dilakukan Judistira dengan membaca buku-buku yang berhubungan dengan kebudayaan Baduy yang ditulis oleh 
para pendahulunya, seperti Jul Jacobs (1891), Pleyte (1909), dan Geise (1952). Selain itu, Garna juga berasal dari etnik Sunda yang kesehariannya menggunakan bahasa Sunda yang juga dipakai oleh orang Baduy sehingga hal ini semakin memudahkan peneliti masuk dan memahami budaya Baduy. Peneliti dalam hal ini Garna, turut membaca buku Jul Jacobs, Pleyte, dan Geise karena peneliti sudah mengerti kebudayaan Baduy dan penulis menggunakan bahasa yang sama dengan bahasa yang dipakai orang Baduy. Hal ini tentunya memudahkan peneliti dalam menyelami isi buku dan memahami apa dibayangkan oleh ketiga penulis tersebut. Sebaliknya, penelitian ini dapat dilakukan dengan baik karena peneliti sudah membaca tentang kebudayaan Baduy. Inilah yang menjadi salah satu contoh dari pemikiran lingkar hermeneutik dalam kualitatif interpretatif. (Kleden, 2012).

Judistira (Garna, 1988c) mengatakan pemahaman atas kebudayaan penting diperhatikan terlebih dahulu, baik pemahaman dengan membaca buku tentang kebudayaan yang akan ditelitinya maupun melakukan pendekatan langsung di lokasi penelitian. Pemahaman ini dimaksudkan agar penelitian tidak menjadi kendala untuk mengungkapkan kebudayaan yang menjadi objek kajiannya baik dari segi metodologi maupun teoretik. Dengan cara seperti itu, hal ini tentunya memudahkan peneliti dalam mendapatkan akses pada gejala-gejala kebudayaan dengan berada dekat pada peristiwa-peristiwa yang terjadi. Peneliti akan mendapat pemahaman tentang gejala yang ditelitinya, meskipun tanpa menggunakan hubungan sebab-akibat. Dari segi metodologi, tentunya penelitian ini terkait dengan pendekatan dan strategis penelitian dari segi ini tampaknya segudang pengalaman di lapangan yang dibuktikan Garna. Dibuktikan dengan terjalinnya hubungan yang baik dengan warga masyarakat yang ditelitinya sehingga beratus-ratus lipat data etnografi yang bercerita dapat dihimpun dan diungkapkan. Begitu pun dari segi teoretik yang digunakan Garna untuk menafsirkan gejala kebudayaan dengan sendirinya telah dipersiapkan. Dari segi ini dapat menggambarkan dan menjelaskan pengetahuan tentang budaya yang ditelitinya.

Etnografi Garna, sebagaimana diterangkan Koentjaraningat atas apa yang dihasilkan Judistira Garna dalam mengkaji kebudayaan Baduy, merupakan etnografi dalam pengertian etnografi sebenarnya sebagaimana yang dikatakan Michael H. Agar (1980). Menurut Agar (1980), kajian etnografi seperti itu berperan dalam dua hal, yaitu sebagai proses dan sekaligus juga sebagai produk. Sebagai produk etnografi yang dihasilkan Judistira tentunya selain berupa buku Orang Baduy, yang telah diulas Koentjaraningrat, juga sebagai suatu proses, "doing ethnography" yang tidak lain. Hasil dari doing ethnography adalah penelitian lapangan dan secara khusus mempelajari manusia dan kebudayaannya yang ditunjukan Judistira melalui disertasi doktor falsafah UKM. Hal yang dilakukan Judistira Garna itu juga dikatakan Spreadly (1980) disebut bekerja etnografis, yaitu melukiskan pengetahuan tentang kebudayaan. Jika menyimak karya etnografi Garna melalui buku Orang Baduy (1987) maupun disertasi Judistira Garna (1988c), maka akan diperoleh pengetahuan mendalam tentang kebudayaan Baduy.

Judistira mengawali penelitiannya dengan menguraikan terlebih dahulu pengetahuan mendalam mengenai orang Baduy berdasarkan anggapan orang Baduy itu sendiri. Anggapan mereka mengatakan kehidupan di dunia ini ialah suatu proses perjalanan yang ditempuh seseorang seperti layaknya suatu pengembaraan, sedangkan sisi mula dari kehidupan yaitu kelahiran yang juga menentukan sekaligus tentang kematian nanti sesuai dengan perjangji. Dalam perjangji itulah, cara-cara tertentu ditetapkan menurut pilihan seseorang untuk menentukan bagaimanakah pengembaraan itu diselesaikan. Pengembaraan itu tentu memerlukan tata cara karena karuhun yang juga pernah mengalami pengembaraan 
seperti itu lalu menyusun pikukuh bagi para keturunannya.

Arah pokok dari pengembaraan itu dijumpai pada salah satu ungkapan dalam pikukuh Baduy yaitu: ... "Ngeumbing ka agama, ngahulu ka hukum" artinya, berpegang pada agama, menghadap pada hukum. Agama dan hukum itu mengacu kepada agama Sunda Wiwitan sebagai sistem kepercayaan orang Baduy. Adapun perjalanan hidup sebagai suatu pengembaraan manusia, antara lain terungkap dalam ungkapan "Ngumbara di Buana Panca Tengah, ngalalana di pasar alas", artinya mengembara di Buana Panca Tengah berkelana di dunia yang penuh tantangan. Bagi siapapun kecuali orang Baduy itu, tafsiran seperti itu membuka peluang untuk membuat setiap tafsir tentang makna pikukuh. Kemudian mereka menganalisis dengan membandingkan tradisi lainnya yang menggunakan landasan teori apa saja yang diyakini seseorang.

Tradisi tinjauan struktural tentang orang Baduy merupakan salah satu tradisi ilmiah yang seringkali dilakukan para ilmuwan Barat. Kajian yang dilakukan Judistira bukan hanya membicarakan orang Baduy dan gejala perubahannya, tetapi cenderung berupaya memahami kehidupan mereka. Gaya pembahasan struktural mungkin pula tidak terlepas sama sekali walaupun akan terdapat perbedaan jelas, yaitu penimbaan empirik dalam kurun waktu panjang terhadap kehidupan orang Baduy itu sendiri, termasuk kegiatan-kegiatan observasi yang dilakukan. Sejumlah pemahaman diperoleh tidaklah digunakan untuk menekan, mengatur, ataupun malahan mendesak dan mengganti tatanan kehidupan mereka menurut aspirasi dan kehendak kita sendiri. Menurut Judistira, "Bahasa kita belum tentu merupakan bahasa mereka. Dewasa ini tengah terjadi penyusupan yang semena-mena dari orang luar, dalam keadaan itu mampukah mereka menyampaikan keinginannya?".
Adaptasi dalam kehidupan sosial orang Baduy sebaiknya dilihat sebagai gejala wajar dari mekanisme budaya yang sebenarnya memperlihatkan ketegaran diri dalam menempuh perjalanan hidup mereka. Karena etnografi Garna tentang kebudayaan Baduy bukan menjadi alat untuk menguasai tatanan kehidupan mereka, tetapi etnografi ini merupakan sumber untuk memahami mereka. Nilai-nilai hidup mereka yang seringkali kita juga cari sejauh mungkin sebaiknya terakomodasikan dalam alur kehidupan yang mereka langsungkan setiap saat. Dengan tercapai sejumlah hasil perubahan sosial budaya baik berupa institusi sosial maupun tata cara baru dapat dinikmati mereka hasil kesediaan dan upaya mereka, bukanlah hasil kerja orang luar belaka.

\section{Pergeseran Wilayah}

Wilayah pemukiman orang Baduy yang sekarang dikenal dengan nama Desa Kanekes yang meliputi wilayah yang lebih luas pada beberapa ratus tahun lalu. Luas wilayah mereka itu dapat ditinjau dari berbagai aspek sosial budaya dan aspek lainnya situs megalitik di beberapa bagian wilayah Banten mengungkapkan penghormatan kepada $\mathrm{ka}$ buyutan, sistem kepercayaan penting pada masyarakat Sunda lama. Dahulu pernah dikenal orang Baduy Karang di wilayah Kecamatan Sajira sekarang, urang Are sebutan orang Baduy terhadap penduduk Islam di sekitar Kanekes. Kelompok masyarakat itu dianggap punya pertalian kerabat dengan orang Baduy.

Apabila dilihat dari sistem kepemimpinan tradisional, maka terdapat wilayah yang cukup luas yang memiliki sistem kepemimpinan semacam yang berlaku dalam kehidupan urang Kanekes, seperti di Banten dan Sukabumi bagian selatan dikenal sesepuh (tetua). Kepemimpinan tradisional yang biasanya terkait dengan tokoh pendahulu kelompok masyarakat atau desa (Garna, 1973) atau dikenal pula dengan istilah sesepuh. Sesepuh mirip dengan posisi dan peranan 
puun, pemimpin adat dan agama yang dianut orang Baduy. Hal ini diperoleh melalui garis keturunan langsung dari tokoh terdahulunya. Pada masyarakat sekitar Kanekes, kepala desa yang dikenal dengan sebutan jaro ialah gabungan kemampuan jawara, sesepuh atau keturunan cikal bakal pendiri desa sedangkan kepala Desa Kanekes disebut jaro atau Jaro Pamarentah serupa dengan sebutan bagi kepala-kepada desa di wilayah itu.

Di dalam situs purbakala, cerita rakyat, sistem kepercayaan dan kepemimpinan, wilayah Baduy meliputi bagian beberapa kecamatan saat ini. Hampir sebagian besar wilayah kecamatan di Kabupaten Lebak, Kecamatan Muncang, Cimarga, Sajira, Maja dan kecamatan Bojongmanik, wilayah tersebut sampai jauh ke Pantai Selatan. Setelah menjadi Desa Kanekes seperti sekarang ini, pikukuh Baduy tidak diperkenankan ada kampung Baduy lain yang letaknya lebih ke selatan (tegasnya lebih girang) dari 3 kampung tangtu. Inti pemukiman Baduy di girang yang terletak dalam lingkungan taneuh larangan.

Pada akhir abad ke-18 diperoleh informasi lebih pasti seperti diungkap van Tricht tahun 1829 bahwa wilayah Baduy terbentang mulai dari Leuwidamar, Cisemeut sampai ke pantai selatan (Garna, 1988c). Sejak penetapan dari Sultan Banten terakhir mengenai batas-batas Kanekes, keadaan wilayah serupa saat ini termasuk daerah Cisimeut. Dengan demikian 7 buah dangka masih terhitung wilayah Kanekes, yaitu: Cibengkung, Kompol, Cihandam, Kamacing, Cilenggor, Nungkulan, dan Panyaweuyan.

Pada awal abad ke-20 sejalan pembukaan perkebunan karet di selatan Banten, masa itu dikenal orang Baduy sebagai zaman Klasiran. Pada zaman ini, tampaknya diadakan pengukuran dan penataan tanah secara tegas oleh pemerintah Hindia Belanda. Untuk keperluan tersebut, kesepakatan antara Sultan Banten dengan orang Baduy mengenai batas-batas Desa Kanekes diambil alih pemerintahan kolonial melalui pengurusan Patih Derus (van Tricht, 1928). Perubahan wilayah itu menyebabkan pergeseran perolehan lahan huma yang dialami orang Baduy, terutama warga kampung panamping. Rotasi huma yang tadinya dianggap ideal berjarak 7 tahun, atau lebih lama lebih baik, dapat ditanami sampai 2-3 kali berturut-turut menjadi waktu jarak tanam semakin lebih singkat pada satu lokasi.

\section{Agama}

Banyak penulis buku tentang orang Baduy selalu menghadapi kesulitan dalam mengemukakan dengan tegas perihal agama yang dianut orang Baduy. Namun, para penulis tampaknya setuju pada pendapat Veth yang membicarakan tentang agama Ciwa-Pajajaran yang juga merupakan agama utama daerah Jawa Barat sebelum agama Islam (Jacobs, 2012). Judistira Garna menguraikan bahwa orang Baduy mengakui hidup ini dan nasib seseorang dikendalikan oleh sesuatu kekuatan gaib yang menguasai seluruhnya, yang mereka sembah dan diberi nama Batara Tunggal.

Aktivitas itu tercermin pada adat yang terdapat pada orang Baduy. Karena itu, orang Baduy bertata laku dan berlaku rupa seperti itu dapat dikatakan sebagai kelompok pertapa dengan cara hidup yang tidak sezaman dari sebelum runtuhnya Pajajaran. Hal ini dibuktikan dengan kenyataan dari kebiasaan yang mereka jalani, seperti tanpa permainan, tak diperkenankan memakai pakaian berwarna menyala, bersolek, atau pada pokok segala sesuatu yang merangsang gairah hidup atau pergantian suasana kehidupan mereka yang monoton. Suatu kebiasaan yang berbeda dijalani orang Sunda sebelum zaman Islam yang tersiarnya pantun-pantun atau kisah pra Islam yang berisi cerita tentang cara hidup penuh kebesaran dan kegemerlapan.

Mengenai seluk beluk pengaturan kehidupan orang Baduy, pemimpin agama yang dikenal puun mengendalikan inti budaya Baduy. 
Kegiatan itu seperti dalam menggarap dan memperlakukan huma serang, ritual dan ritus keagamaan, sakit dan kematian serta kehidupan sesudah kematian termasuk pula menerjemahkan tanda-tanda alam yang luar biasa menggerakkan aktivitas orang Baduy. Pengaturan itu juga termasuk pengaturan kehidupan di dalam kampung dan menata kehidupan di rumah (Kartawinata, 2002). Garna memberikan gambaran tentang karakter orang Baduy yang memperlihatkan tanda-tanda mampu menahan gejolak hatinya dan tidak terikat kebiasaan terhadap atasan. Sebagai contohnya pada orang Jawa, Sunda atau suku lainnya, hormat yang berlebihan seperti biasa diperlihatkan oleh tetangganya, tidaklah dilakukan oleh mereka dan dengan bebas berhadapan dengan pembicara.

Orang Baduy juga tidak mengenal istilah kemewahan dalam arti yang biasa. Kemewahan dalam makna kenikmatan bagi orang Baduy terletak dalam keadaan huma yang penuh kesuburan, pada kesehatan diri sendiri, dan untuk siapa bekerja yang memberikan timbal balik untuk memperindah kehidupan. Permusuhan selalu dihindarkan karena kesusilaan pada umum dan kesusilaan khusus bagi orang Baduy sangat dijunjung tinggi. Itu artinya perilaku pada setiap aktivitas yang berlangsung dalam lingkungan rumah tangga bertujuan untuk menopang kehidupan yang selaras dengan lingkungan alam dan lingkungan sosial tempat mereka tinggal.

Buyut atau tabu pada setiap aktivitas kehidupan di rumah tangga dan keluarga yang terkait dengan pekerjaan dan bagaimana mereka memperoleh bahan makanan serta aktivitas keseharian yang dilakukan orang Baduy. Aktivitas yang dilakukan itu, seperti dalam aktivitas mengolah tanah dan memperlakukan hasil huma, pengaturan warisan, serta menjaga keamanan di lingkungan permukiman. Pengaturan waris bagi orang Baduy berlaku di mana jika suami meninggal, istri mempunyai hak menikmati hasil dari seluruh yang ditinggalkan. Namun, ini tidak bebas untuk dalam hal pengurusannya karena harta itu digunakan untuk menghidupi anak-anaknya. Harta itu akan diwariskan kepada anak-anaknya. Jika istrinya pun meninggal dengan pembagian $2 / 3$ bagian untuk anak laki-laki dan $1 / 3$ bagian untuk anak perempuan. Jika tidak ada sanak keluarga sama sekali, maka warisan dibagi rata antara puun, girang seurat, dan kokolot. Pengertian orang Baduy tentang agama Sunda Wiwitan ialah relasi antara cara berpikir dengan tingkah laku menurut yang digariskan pikukuh. Sementara itu, pemahaman dari pikukuh itu sendiri adalah aturan dan tatacara atau pedoman bagaimana seharusnya melakukan perjalanan hidup yang tidak melanggar amanat karuhun (Moechtar, $t \mathrm{tt}$ ). Pikukuh Baduy tentang buyut diutarakan dalam buyut titipan karuhun seperti diungkapkan oleh Moehtar, tt), sebagai berikut:
Gunung teu meunang dilebur, Lebak teu meunang diruksak,

Larangan teu meunang dirempak, Buyut teu meunang dirobah,

\section{Lojor teu meunang} dipotong,

Pondok teu meunang disambung,

$\mathrm{Nu}$ lain kudu

dilainkeun,

Nu ulah kudu diulahkeun,

Nu enya kudu dienyakan.
Gunung tidak boleh digempur,

Lembah tidak boleh dirusak, Larangan tidak boleh dilanggar, Tabu tidak boleh dirubah, Panjang tidak boleh dipotong, Pendek tidak boleh disambung,

Yang lain harus dipandang lain, Yang dilarang harus dilarang,

Yang betul harus dipandang betul.
Istilah buyut mempunyai beberapa makna. Selain suci dan tabu, buyut juga berarti sejumlah hal yang dilarang, atau teu meunang dan menjadi pedoman, sebagaimana pikukuh. Kaitan antara satu buyut dengan buyut yang lain selalu ada, seolah tidak terbatas, berdimensi luas dan kadangkala lentur menampung hal-hal lain yang mungkin terkait dengannya, tetapi bukan berarti menunjukkan ketidakpastian karena 
ketentuan-ketentuannya tegas.

\section{Kelompok Asal Keturunan}

Orang Baduy mengelompok menurut asal keturunan tangtu, yaitu keluarga luas yang tinggal dalam satu kampung. Ada 3 kelompok kekerabatan dalam kesatuan orang tangtu, yaitu Cibeo, Cikartawana, dan tangtu Cikeusik. Adapun hirarki kekerabatan itu sesuai dengan urutan dari yang paling tua ke yang paling muda, yaitu Cikeusik, Cikartawana, dan Cibeo. Garna (1973) mengatakan bahwa orientasi kekerabatan cenderung kepada pihak ibu ( $a m b u)$, tetapi biasanya seorang laki-laki membawa istrinya ke kampung tempat tinggal keluarga luasnya dan membuat rumah baru. Dalam upacara-upacara keagamaan Sunda Wiwitan, mereka mengikuti kampung asal istrinya. Keadaan itu tampaknya tidak berlaku mutlak bagi seorang wanita yang mengikuti keluarga luas suaminya karena seorang pria juga dapat mengikuti istri ke kampung asalnya.

Desa Kanekes terbagi dalam dua wilayah penting, yaitu wilayah tangtu (sakral) dan wilayah panamping (profan). Makin ke arah selatan daerahnya, makin sakral sedangkan daerah tersuci adalah hulu Ciujung, tempat Sasaka Pusaka Buana yang lebih dikenal dengan sebutan Sasaka Domas. Derajat sakral dilihat menurut bagian kampung dengan arah seperti itu dan berlaku pula di hampir setiap kampung panamping. Rumah kokolot (ketua adat dan agama) adalah daerah sakral dan bagian belakang rumah biasanya bersambung ke hutan kampung. Di daerah kampung tangtu yang sakral pun masih terdapat daerah tersakral yang tidak boleh diinjak orang luar, yaitu rumah puun dan daerah sekitarnya.

Dalam konteks itu, pembagian yang memotong seluruh warga masyarakat Baduy dalam dua paroh masyarakat, yaitu tangtu dan panamping. Dua paroh ini menentukan posisi masing-masing dalam rangka suatu kesatuan masyarakat. Peranan untuk saling mengenda- likan dan mengawasi ditentukan berdasarkan sistem pajaroan yang dibentuk serta dipimpin oleh tangtu atau tiga puun. Puun mengangkat seorang jaro, yaitu tanggungan jaro duawelas yang bertugas mengawasi para jaro, terutama para jaro di panamping dan kampung dangka.

\section{Kampung dan Ikatan Kerabat}

Untuk melihat kekerabatan orang Baduy, lokasi tempat tinggal mereka dianggap penting. Lokasi permukiman itu menentukan seseorang berada pada kedudukan yang mana sebagai keturunan para Batara. Selain itu, lokasi dapat dilihat dari berbagai sistem sosial lainnya, seperti perkawinan, pola tempat tinggal sesudah kawin, penempatan rumah di kampung yang dapat memberikan gambaran tentang kekerabatan dan kedudukannya dalam masyarakat.

Hubungan antara sistem kekerabatan dan lokasi kampung dapat dilihat dari tiga sisi, yaitu: pertama tentang kampung tangtu; kedua, kampung panamping; dan ketiga pajaroan. Mengenai hal tersebut, ekspresi orang Baduy menggambarkan bahwa seluruh wilayah Desa Kanekes adalah tangtu teulu jaro tujuh (Kartawinata, 1984; 2002). Artinya bahwa wilayah Kanekes seluruh penduduknya merupakan satu kerabat yang berasal dari satu nenek moyang, kalau pun ada perbedaan terletak pada tua dan muda dari sisi generasi.

Dalam kekerabatan orang Baduy (Garna, et al, 2016), Cikeusik dianggap yang tertua, Cikartawana yang menengah dan Cibeo yang termuda. Oleh karena itu, Puun Cikeusik yang mengurus kunjungan tahunan ke Sasaka Domas tempat yang disucikan oleh orang Baduy. Kerabat yang lebih muda cukup denganmengikuti yang tertua. Selain itu, pembagian kombala berupa tanah putih dan lumut yang dibawa dari tempat itu yang mengikuti ketentuan kerabat tua dan muda. Untuk memudahkan pembahasan kampung dan kekerabatan, istilah 
kekerabatan atau kinship dalam Etnografi Garna mengacu pada sejumlah status (posisi atau kedudukan sosial), dan saling hubungan antarstatus. Hal tersebut sesuai dengan prinsip-prinsip budaya yang berlaku terutama digunakan untuk: (1) menarik garis pemisah antara kaum-kerabat (kin) dan bukan kaum-kerabat (non-kin); (2) menentukan hubungan kekerabatan seseorang dengan yang lain secara tepat; (3) mengukur jauh/dekatnya hubungan kekerabatan seseorang dengan yang lain; dan (4) menentukan bagaimana seseorang harus berperilaku terhadap seseorang yang lain sesuai dengan aturan-aturan kekerabatan yang disepakati bersama.

Judistira Garna (1993; 2016), menggambarkan prinsip-prinsip budaya Baduy tersebut bahwa dalam perkawinan kecenderungan yang dianggap paling baik, di mana perkawinan anak laki-laki yang pertama (kakak) dari suatu garis keturunan dengan anak perempuan yang terakhir (adik) dari garis keturunan yang lain. Hal tersebut yang dianggap penting dalam kaitan dengan ketentuan itu adalah adik tidak boleh melangsungkan perkawinan sebelum kakaknya melangsungkan perkawinan (ngarunghal). Dalam praktiknya orang Baduy, tidak terdapat perbedaan antara sepupu persamaan (paralel-cousins) dan antarsepupu (cross-cousins) (Garna,1987). Hal ini menimbulkan adanya kecenderungan dalam perkawinan itu terjadi dalam keluarga yang paling dekat dapat terjadi sampai dengan sepupu tingkat keempat dengan istilah orang Baduy disebut baraya.

Di dalam kaitan itu, Garna (1985) melihat bahwa antara dangka dan tangtu diibaratkan seperti rangka dengan isi yang pasti, yaitu tangtu merupakan nenek moyang atau karukun yang dengan istilah lain sebagai pusat dan dangka sebagai isi dari seluruh keturunannya. Dangka adalah tempat tinggal bagi warga sedangkan tangtu yang adalah untuk sementara waktu tinggal di sana karena melanggar adat sebagaimana ditentukan oleh nenek moyang. Untuk sementara sampai dosanya dianggap lebur, orang tangtu yang tinggal di dangka sebenarnya masih satu keluarga dengan warga kampung tangtu yang mengirimkan mereka ke sana. Jika mereka yang di dangka itu tidak dapat atau tidak mau kembali ke tangtu, maka mereka tetap merupakan kerabat dekat. Dari istilah warga dangka mereka itu disebut kaum dangka dan sebutan tersebut menunjukkan bahwa mereka masih segolongan atau sekerabat dengan warga tangtu.

Dapat dikatakan bahwa warga kampung dang$k a$ berkerabat dekat dengan 3 kampung tangtu Cikeusik berkerabat dekat dengan warga dangka Cibengkung, Kompol dan dangka Kamancing, sedangkan tangtu Cikartawana berkerabat dekat dengan dangka Cilenggor, Nungkulan dan dangka Panyaweuyan, dan tangtu Cibeo berkerabat dengan dangka Cihandam. Ikatan kerabat yang dekat itu berlaku pula terhadap warga yang tinggal di kampung-kampung panamping yang warganya disebut kaum daleum (Kartawinata, 1994). Warga kampung tangtu Cikeusik berhubungan kerabat yang erat dengan warga panamping Pamoean dan panamping Cipiit, sedangkan warga tangtu Cikartawana berkerabat dekat dengan warga panamping Cikopeng, dan tangtu Cibeo berkerabat dengan panamping Gajeboh, Kaduketer, dan panamping Cihulu.

\section{Simpulan}

Etnografi Garna adalah gambaran mendalam mengenai pengetahuan kebudayaan Baduy sesuai dengan makna dari objeknya. Oleh karena itu, karya ini dapat dilihat sebagai karya etnografi yang kaya dengan informasi mengenai kehidupan orang Baduy dan tanggapan mereka terhadap perubahan dari perspektif orang Baduy itu sendiri. Selain itu, karya ini juga mengungkapkan hal ihwal yang terkait dengan bagaimana mereka menyikapi perubahan.

Pertama, bagi orang Baduy keberlangsungan kebudayaan selalu identik dengan mempertahankan keberadaan leluhurnya, termasuk menjalankan ajaran yang diturunkannya 
dengan penuh ketaatan dan penghormatan. Hal itu dilakukan untuk menjaga keseimbangan yang harmonis antara kehidupan nyata di alam ini dengan kehidupan yang gaib. Ajaran yang mereka yakini itu diterapkan dengan penuh kesetiaan pada setiap keluarga di kampung-kampung tangtu, panamping, pajaroan, dangka. Ini karena kampung bagi mereka bukan hanya tempat hidup dalam satuan-satuan rumah yang berasingan, tetapi merupakan ikatan sosial antarpenghuni rumah satu dengan rumah lainya untuk terpelihara keseimbangan yang adil. Keseimbangan yang adil untuk tetap berlangsungnya kehidupan antarkeluarga, antarwarga kampung, antara yang memimpin dan yang dipimpin, keseimbangan dalam penggunaan dan memanfaatkan alam untuk bekal kehidupan (Diamond, 2017). Semua itu dipancarkan dalam kehidupan kampung yang harmonis, satu keluarga dengan keluarga lain dalam kampung tidak mengenal perbedaan fisik, wujud atau bentuk rumah, isi rumah, atau pun tampilan gaya hidup. Curahan kehidupan yang sedemikian itu oleh Diamond (2017) disebut untuk menjaga keseimbangan yang telah diciptakan leluhur agar tidak dirusaknya, melainkan mereka menegakkan keseimbangan itu dengan adil tanpa upaya untuk mengurangi keseimbangan.

Kedua, pembagian ruang budaya yang merujuk pada wilayah tangtu, dan wilayah panamping merupakan mekanisme keberlanjutan budaya Baduy yang terkait dengan kompleksitas kepemimpinan yang mengatur kehidupan urang Kanekes (Kartawinata, 2002). Kompleksitas kepemimpinan yang direproduksi oleh masyarakat karena berhubungan dengan tindakan dan tanggung jawab (Holaday, 2016). Dalam konteks itu, tindakan dan tanggung jawab kepemimpinan berfungsi mengatur kehidupan sosial yang diwujudkan oleh masyarakat melalui sikap kepatuhan dan ketaatan (Kartawinata, 2002). Hal itu sejalan dengan pendapat Ernest Brandewie (2000) mengenai bagaimana konsep kepemimpinan dioperasional berdasarkan kekerabatan. Atau konsep Berthe (2000) tentang oposisi dalam sistem kekerabatan orang Baduy yang diwujudkan dalam organisasi sosial. Berdasarkan kedua konsep kepemimpinan dalam konteks kekerabatan tersebut, hal ini mencerminkan ketaatan dan kepatuhan pengikut menjadi pangkal utama berlangsungnya proses kepemimpinan. Sebagai imbalan dari ketaatan dan kepatuhan pengikutnya, seorang pemimpin menunjukkan dirinya dengan mampu memenuhi kebutuhan warga masyarakatnya. Karena itu, hubungan antara pemimpin dan pengikut dijalin melalui ikatan kekerabatan dengan merujuk pada garis keturunan yang paling tua dan garis keturunan yang paling muda dalam terminologi kekerabatan. Putaran kekerabatan serupa itu oleh Berthe disebut sebagai oposisi dalam kekerabatan yang diwujudkan dalam organisasi sosial atau pengaturan kehidupan sosio-budaya masyarakat Baduy.

Ketiga, budaya Baduy hingga kini masih bertahan dari berbagai pengaruh luar, baik agama maupun teknologi pertanian yang sederhana. Mereka diikat hirarki ikatan kerabat dalam pajaroan yang bukan hanya mengatur kehidupan keseharian mereka, tetapi juga keagamaan warga masyarakat Baduy. Hirarki $p a-$ jaroan yang meski telah dipengaruhi sistem pemerintahan modern yang ditampilkan melalui pemerintahan desa, melainkan dalam praktiknya pengaturan kehidupan keseharian warga masyarakat Kanekes. Warga Kanekes sepenuhnya masih di bawah kendali para pemimpin yang ditunjuk puun sebagai pucuk pimpinan mereka yang berkedudukan di tiga kampung tangtu, yaitu Cikeusik, Cikartawana dan Cibeo. Dalam praktek kepemimpinan ketiga puun mempunyai fungsi yang berbeda sesuai dengan kedudukan dan peranannya masing-masing dalam hirarki kekerabatan. Dalam kedudukan ini, Puun Cibeo berfungsi sebagai pemimpin kehidupan sosial yang mengatur aktivitas warga masyarakatnya, puun ini dihubungkan oleh garis keturunan yang paling muda, dan Puun Cikeusik berfungsi memimpin kegiatan keagamaan yang ditentukan oleh garis keturunan yang paling tua, 
sementara Puun Cikartawana kedudukannya di antara kepemimpinan agama dan kepemimpinan kehidupan sosial yang berperan sebagai penyeimbang dunia nyata dan dunia gaib. Tanggung jawab yang terkait dengan agama dilakukan oleh Puun Cikeusik selalu dihubungkan dengan karuhun untuk memelihara identitas budaya. Lain halnya dengan tanggung jawab sosial yang dijalankan Puun Cibeo, yang mana selalu dihubungkan dengan manusia untuk dapat memenuhi kebutuhan hidup duniawi.

\section{Daftar Pustaka}

Agar, M. H. (1980). The Profesional Stranger; An Informal Introduction to Ethnography. Orlando, San Diego, New York: Academic Press, Inc.

Benyamin, G. (2016). Indigeny Exogeny The Fundamental Social Dimension? ANTHROPOS-111, 513-531.

Berthe, L. (2000). Kekerabatan, Kekuasaan dan Cara Berproduksi. Terjemahan Salam Hardjadilaga. Bandung: Primaco Akademika.

Brandewie, E. (2000). Tempat Orang Besar dalam Masyarakat Hagen Tradisional di Dataran Tinggi Tengah Nugini. Dalam F. M. Tuden, Pendekatan Antropologi pada Perilaku Politik. Terjemahan Suwargono dan Nugroho (hal. 85-112). Jakarta: Penerbit Universitas Indonesia.

Diamond, J. (2017). Dunia Hingga Kemarin: Apa yang dapat Kita pelajari dari Masyarakat Tradisional . Jakarta: Kepustakaan Populer Gramedia.

Dilthey, W. (1976). Selected Writings. Cambridge, London, New York, Melbourne: Cambridge University Press.

Garna, J. K. (1973). Kasepuhan Sirnaresmi Studi Tentang Kepemimpinan Tradisional di Sukabumi (Banten) Selatan. Bandung: Universitas Padjadjaran.

Garna, J. K. (1985). Masyarakat Baduy dan Kebudayaannya. Bandung: Pusat Kajian dan Pengembangan Sosial-Budaya Institut Teknologi Adityawarman.

Garna, J. K. (1987). Orang Baduy. Bangi Selanggor Darul Ehsan: Penerbit Universiti Kebangsaan Malaysia.
Garna, J. K. (1988a). Nyi Pohaci Sanghyang Asri. Dalam N. Rangkuti, Orang Baduy Dari Inti Jagat (pp. 60 - 66). Jakarta: Bentara Budaya bekerjasama dengan Harian Kompas, Etnodata.

Garna, J. K. (1988b). Perubahan Sosial Budaya Banduy. Dalam N. Rangkuti, Orang Baduy Dari Inti Jagat (hal. 47-59). Jakarta, DKI Jakarta, Indonesia: Bentara Budaya Bekerjasama dengan Harian Kompas Etnodata.

Garna, J. K. (1988c). Tangtu Telu Jaro Tujuh Kajian Struktural Masyarakat Baduy di Banten Selatan Jawa Barat Indonesia. Bangi: Thesis - Universiti Kebangsaan Malaysia.

Garna, J. K. (1993). Orang Baduy di Jawa Barat: Sebuah Studi Kasus Mengenai Adaptasi Suku Asli terhadap Pembangunan. Dalam L. T. Gomes, Suku Asli dan Pembangunan di Asia Tenggara. Terjemahan A. Setiawan Abadi (hal. 142-160). Jakarta: Yayasan Obor Indonesia.

Garna, Judistira K., Ade Makmur K, Dede Mariana, dan Ari Ganjar. (2016). Kampung Culture: Why Kampung Baduy is in Peace and Balanced? Dewan Tuanku Canselor ISUM - Negeri Sembilan: International Conference on Kampung Mizan, 24 25 September - Universiti Sains Islam Malaysia.

Geertz, C. (1973). The Interpretation of Cultures. New York: Basic Books, Inc, Publischer.

Geise, N. (1952). Badujs en Moslims in Lebak Parahiang Zuid Banten. Leiden: N.V. Grafisch Bedrijf en Uitgeverij de Jong.

Hodder, I. (2009). Interpretasi Dokumen dan Kebudayaan Materi, terjemahan Dariyatno dkk. In N. K. Lincoln, Handbook of Qualitative Reserach (pp. 544557). Yogyakarta: Pustaka Pelajar.

Holaday, Y. (2016). Notes on Politic and Philosophy in Orang Asli. In E. K. (Ed), Malaysia's Original People: Past, Present and Future of the Orang Asli (pp. 41-56). Singapore: NUS Press.

Iskandar, J. (1992). Ekologi Perladangan Indonesia: Studi Kasus dari Daerah Baduy Banten Selatan. Jakarta: Penerbit Djembatan, .

Iskandar, Johan dan Budiawati Supangkat Iskandar. (2017). Kearifan Ekologi Orang Baduy dalam Konservasi Padi dengan 
"Sistem Leuit". Jurnal Biojati, 2 (1), 3851.

Jacobs, J. (2012). Etnografi Jul Jacobs Alih Bahasa Salam Hardjadilaga dan Judistira K. Garna. Bandung: Penerbit Primaco Akademika.

Kartawinata, A. M. (1984, 22 Februari). Membuka Kebudayaan Baduy Tak Hanya Asal Tebas. Bandung: Surat Kabar Pikiran Rakyat.

Kartawinata, A. M. (1994). Etnografi mengenai Suku-suku Asli Resensi Buku Lim Teck Ghee dan Alberto G. Gomes, Suku Asli di Asia Tenggara. Terjemahan A. Setiawan (Tribal Peoples and Development in South-east Asia). Jakarta: Surat Kabar Kompas.

Kartawinata, A. M. (1995). Tidak Sekadar Program Bantuan atau IDT: Konsep Pembangunan Masyarakat Baduy. Bandung: Surat Kabar Pikiran Rakyat.

Kartawinata, A. M. (2012). Etnografi Jul Jacobs Orang Baduy dari Banten. Bandung - Baituna Guest House 2 November 2012: Makalah pada Peluncuran Buku Seri Etnografi Baduy 1: Etnografi Jul Jacobs: Orang Baduy Tinjauan atas Buku De Badoej's, Jul Jacobs, 'S-Gravenhage: Marthius Nijhoff, 1891. terjemahan Judistira K. Garna - Salam Hardjadilaga. Bandung: Primaco Akademika, 2012.

Kartawinata, Ade M; dan Adi Puwanto. (2002). Pamarentahan Baduy di Desa Kanekes Perspektif Kekerabatan. Jurnal Sosiohumaniora Vo. 4 Juli 2002.

Kartodirjo, S. (1993). Metode Penggunaan Bahan Dokumen. Dalam Koentjaraningrat, MetodeMetode Penelitian Masyarakat (pp. 44-69). Jakarta: PT Gramedia Pustaka Utama.

Kleden-Probonegoro, N. (2012). Etnografi: Membuat Data Bercerita. Jurnal Masyarakat \& Budaya Volume 14, No. 1, 1-30.

Koentjaraningrat. (1988). Tafsir Kebudayaan, dengan contoh Kebudayaan Baduy. Dalam N. Rangkuti, Orang Baduy Dari Inti Jagat (hal. 38-46). Jakarta: Bentara Budaya bekerjasama dengan Harian Kompas, dan Etnodata.

Lee, K. C. (1976). Indonesia between Myth and Reality. London: Nile \& Mackenzie.

Lee, K. C. (1999). THE BADUIS The Isolationists. In L. K. Choy, A fragile nation : the Indonesian crisis (pp. 167-180). Singapore: World
Scientific Publishing Co. Pte. Ltd.

Moechtar, R. (-). Nganjang Ka Baduy. Majalah Bahasa Sunda Mangle Nomor 471, 16-17.

Saat, G. (2019). Community, as the Concept and Method in Social Sciences Research: Sociological Interpretation. Akademika 89(3), Oktober, 53-62.

Saleh Danasasmita dan Anis Djatisunda. (1985). Kehidupan Masyarakat Kanekes. Bandung: Proyek Sundanologi Departemen Pendidikan dan Kebudayaan RI.

Smith, L. M. (2009). Metode Biografis, terjemahan Dariyatno dkk. Dalam N. K. Lincoln, Handbook of Qualitative Research (pp. 365-392). New Delhi: Sage Publication.

Spradley, J. P. (1980). Participant Observation. Florida: Holt, Rinehart and Winston.

Zed, Mestika. (2014). Metode Penelitian Kepustakaan. Jakarta: Yayasan Pustaka Obor Indonesia. 
